\title{
Andrzej Murzyn, Bogusław Śliwerski: \\ Irlandia. Zielona wyspa międzykulturowej edukacji, opieki i wychowania. Kraków 2020, Oficyna Wydawnicza „Impuls”,
}

SS. 159

ISBN: 978-83-8095-886-9

Książka autorstwa Andrzeja Murzyna i Bogusława Śliwerskiego jest istotną publikacją dotyczącą słabo eksponowanego w polskiej literaturze komparatystycznej kraju, jakim jest Irlandia. Niewątpliwie monograficzne ujęcie tematu zaproponowane przez autorów, połączenie zagadnień ideologii edukacyjnych i tradycji historycznych z nowymi wyzwaniami stojącymi przed edukacją w Irlandii stanowią walor książki. Może być ona przyczynkiem do głębszego namysłu nad relacją trwałości i zmienności rozwiązań systemowych w Irlandii, a także dobrym punktem odniesienia do zastanowienia nad kształtem polskich rozwiązań stosowanych w polityce oświatowej. Książka stanowi interesującą propozycję z zakresu polityki oświatowej i pedagogiki porównawczej, prezentowanej w kontekście społecznym. Autorzy prezentują zwięzłą charakterystykę wybranych kwestii dotyczących funkcjonalności edukacyjnych rozwiązań w słabo dotychczas omawianej przez polskich komparatystów Irlandii.

Już we wstępie Autorzy uzasadniają wybór tematu książki następująco: „Badacze procesów socjalizacyjnych, wychowawczych, opiekuńczych, a szczególnie edukacyjnych, sięgając do osiągnięć państw Zjednoczonego Królestwa Wielkiej Brytanii, najczęściej koncentrują swoją uwagę na Anglii i Walii, rzadziej badając te procesy w Szkocji i Irlandii Północnej. Postanowiliśmy dopełnić tej luki, by wiedza o ideach i rozwiązaniach praktycznych znalazła swoje odzwierciedlenie także w odniesieniu do tego ostatniego z państw, o którym pisze się, że (...) Irlandia XXI wieku stanowi jedno z najbardziej nierównych społeczeństw Europy. Nierówność idzie często w parze z sytuacją, kiedy ludzie identyfikują się często jako odmienni lub gorsi od większości populacji. Stereotypy, uprzedzenia, dyskryminacja, homofobia 
i rasizm to zła strona zróżnicowanego społeczeństwa, w którym żyjemy. Polscy socjolodzy wskazują na to, że to nasz kraj przewodzi na kontynencie europejskim najwyższym stopniem rozwarstwienia społecznego. Może zatem warto przyjrzeć się temu, jak Irlandczycy radzą sobie z tym zjawiskiem, od szeregu lat włączając w proces koniecznej naprawy także edukację szkolną". (Wstęp, s. 12). I słusznie piszą autorzy, że Irlandia jest słabo eksponowanym krajem w literaturze komparatystycznej, zresztą od wielu lat analizy komparatystyczne w Polsce w swojej naukowej odsłonie nie są „w modzie”. Poza uznanymi publikacjami, m.in. Eugenii Potulickiej, Zbyszko Melosika, dyskursy komparatystyczne osadzone w kontekście anglosaskim są słabo reprezentowane. Pedagogika porównawcza jest subdyscypliną nauk o wychowaniu złożoną, trudną, wymagającą przygotowania do ujmowania problemów w sposób interdyscyplinarny, wymaga studiów literatury obcojęzycznej, a nade wszystko, rozległej wiedzy o procesach decydujących o kształcie edukacji w danym kraju, jego historii i fenomenach społecznych, znajomości kontekstu kulturowego i tła politycznego.

Tym bardziej istotne jest podejmowanie się nowych, aktualnych tematów komparatystycznych przez uznanych pedagogów, którzy poprzez wiedzę, ale i doświadczenie pisarskie są w stanie ująć syntetycznie najważniejsze kwestie naukowej eksploracji, ukazując je w sposób logiczny i spójny, interesujący i z troską o adekwatny aparat pojęciowy przynależny pedagogice porównawczej.

Jak piszą autorzy we wstępie do książki, postanowili oni „włączyć się swoją analizą w zmianę paradygmatu w pedagogice porównawczej, która polega na przemieszczeniu procesu systematyzacji wiedzy o systemie szkolnym ku perspektywie kontekstualnej, interpretacyjnej i problemowej, uwzględniającej tło historyczne, polityczne i społeczno-kulturowe" (s. 19). Nie jest to ujęcie nowe, bowiem większość obecnych w dyskursie komparatystycznym monografii analizy kontekstualne prowadzi, zresztą trudno sobie bez nich wyobrazić rzetelne badania porównawcze. Autorzy recenzowanej książki odwołują się do aktualnego stanu badań w zakresie pedagogiki porównawczej, przy czym paradygmat, w którym rozprawa jest osadzona, ma jednak charakter dosyć zachowawczy, by nie rzec - tradycyjny. Dominującym zabiegiem intelektualnym jest zebranie danych i ich prezentacja, ale także próba wyjaśnienia wybranych zagadnień problemowych.

Warto zauważyć, że zagadnienia opisowe są obecnie uaktualniane na stronach Komisji Europejskiej i sieci Eurydice i są to publikacje zarówno w języku polskim, jak i angielskim dostępne w otwartych zasobach. Mam na 
myśli chociażby Zestawienie systemów edukacji w krajach Unii Europejskiej $i$ EOG ${ }^{1}$, czy też The Structure of the European Education Systems Schematic Diagrams Eurydice - Facts and Figures ${ }^{2}$. Tym bardziej niezrozumiały jest fakt powoływania się na nieaktualne dane dotyczące struktur systemu szkolnego przedstawione w książce Dobromira Dziewulaka wydanej w roku 1997. Żałuję, że nie znalazły odzwierciedlenia w podstawach teoretycznych książki uznane prace z zakresu pedagogiki porównawczej, jak choćby Roberta Cowena, Andreasa M. Kazamiasa: International Handbook of Comparative Education (Cowen Robert, Kazamias, Andreas M., 2009), Marka Braya, Roberta Adamsona, Boba Roberta, Marka Masona: Comparative Education Research. Approaches and Methods (Bray, Mark, Adamson, Robert Bob, Mason, Mark 2014) czy Davida Phillipsa i Michele Schweisfuhrt: Comparative and International Education. An Introduction to Theory, Method and Practice (Phillips, Schweisfuhrt 2014). Zapoznanie się z przedstawianymi w nich nowymi ujęciami zagadnień komparatystyki pedagogicznej być może pozwoliłoby na uniknięcie zbytniego rozdrobnienia zagadnień problemowych przy jednoczesnym dość pobieżnym, a czasem nieprawidłowym przedstawieniu zagadnień, jak choćby błędne zapisy w strukturze organizacji szkolnictwa na stronie 53 monografii (jest to zapewne wynik odwołania do nieaktualnego źródła wspomnianego wyżej - książki Dobromira Dziewulaka, która być może interesująca dla czytelnika w drugiej połowie lat 90 . XX wieku - dziś może być dla analiz porównawczych wręcz - ze względu na archaiczne dane - szkodliwa).

Interesujące są z pewnością przedstawiane przez autorów analizy dotyczące opieki nad dziećmi. Fundamentem tych analiz jest teoria C. Murraya i M. Urbana na temat uwarunkowań społeczno-edukacyjnych rozwoju najmłodszych dzieci w Irlandii, w Polsce słabo znana. Autorzy ze szczególną starannością analizują pracę z dziećmi wywodzącymi się z różnych kultur, w tym działania dające odpór uciskowi na tle etnicznym i religijnym oraz prezentują dobre praktyki na rzecz praw dziecka. Interesujący jest opis podejmowanych przez Irlandczyków działań antydyskryminacyjnych: ustalenie minimalnych standardów zapewniających godne życie każdemu dziecku, niedyskryminacji, dbałości o najlepsze interesy dziecka, zapewnienie prawa do życia oraz prawa do uczestnictwa w życiu społecznym. Ustawa o opiece nad dziećmi

1 Eurydice. Krótkie opisy systemów edukacji. https://eurydice.org.pl/wp-content/ uploads/2014/10/irlandia.pdf, dostęp: 14.07.2021.

2 Eurydice. The Structure of the European Education Systems Schematic Diagrams 2020/2021. https://eurydice.org.pl/wp-content/uploads/2020/11/the_structure_of_ the_european_education_systems_2020-21.pdf, dostęp: 14.07.2021. 
z roku 2016 po raz pierwszy zapewniła prawne podstawy dla ochrony dziecka oraz edukacji małych dzieci, od tej pory Irlandia coraz częściej zwraca uwagę na zjawisko niezaspakajania w sposób należyty potrzeb dzieci oraz konieczność troski o rozwój i przeciwdziałanie nierównościom społecznym, w tym ubóstwu. Dzięki książce Murzyna i Śliwerskiego zagadnienia te stają się czytelnikowi bardziej znane.

Niektóre, choć niewielkie, partie tekstu mogłyby w mojej ocenie być nieco inaczej ujęte. Być może, zwłaszcza w rozdziale 4, niekonieczne jest tak liczne „rozczłonkowanie” prowadzonej przez Autorów analizy zjawisk społecznych oraz postaw społecznych. Umocowanie w tradycyjnym paradygmacie czyni rozprawę bardzo dobrą $w$ warstwie deskryptywnej, nieco słabiej prezentuje się aspekt wyjaśniający. W mojej ocenie niektóre niezwykle interesujące zagadnienia zostały jedynie zasygnalizowane, jak choćby wspomniane wyżej zagadnienia społeczne i fenomeny społeczne prezentowane w rozdziałach od trzeciego do piątego, które same w sobie już mogłyby tworzyć fundament do powstania kolejnej książki i pogłębienia refleksji nad specyfiką socjologicznego i kulturowego tła procesów edukacyjnych zachodzących w Irlandii.

Książka jawi się jako wartościowa propozycja, uzupełniająca niedostatek w literaturze komparatystycznej na polskim rynku wydawniczym dotyczący Zielonej Wyspy. Założenie koncepcyjne pracy jest zatem wartościowe poznawczo. Autorzy postanowili omówić wybrane przez siebie, ich zdaniem, istotne aspekty systemu edukacyjnego Irlandii, ale również nie unikają kwestii historycznych w przemianach tego systemu edukacyjnego, odwołują się do trudności w ujmowaniu irlandzkiej „jedności” i próbują ukazać w dyskursie komparatystycznym, w jaki sposób ideologia, a także historyczne i społeczne uwarunkowania mogą wpływać na strukturę i funkcjonowanie systemu edukacyjnego.

Książka Andrzeja Murzyna i Bogusława Śliwerskiego może być pomocna w zrozumieniu specyfiki „Zielonej Wyspy”, a także kulturowych, społecznych i politycznych procesów, które wpływają na obecnie podejmowane w tym kraju reformy edukacyjne; może być także wykorzystywana przez nauczycieli akademickich i studentów w procesie dydaktycznym, prowadzonym w uczelniach w zakresie pedagogiki porównawczej. 